\title{
Floral analysis can be use as an early plant analytical tool to diagnose nutritional status of fruit trees?
}

\author{
Nagy, P.T. \\ Department of Agricultural Chemistry, Centre of Agricultural Sciences and Engineering, University of Debrecen, \\ Hungary, H-4032 Debrecen, Böszörményi Street 138.
}

Summary: A field experiment was conducted in an integrated apple orchard (Malus domestica Borkh.) established on a lowland chernozem soil in East-Hungary, to investigate if flower analysis could be used to diagnose the nutritional status of the trees. In April 2008 , during full bloom, flowers and leaves were collected. Leaves were collected again in August, at the standard sampling time from the same trees. The content of nitrogen, phosphorous, potassium, calcium magnesium and boron were measured in flowers and in leaves. Correlation analyses were carried out to establish the relations between nutrient contents in same and different plant parts. In flowers the following ratio was found between nutrients: N:P:K:Ca:Mg:B 10:1.35:7:1.7:1:0,02. From results it was evident that flower as organ contain significant and comparable amount of nutrients like as leaf. The N, K and Ca content were higher in leaves than in flowers at full bloom. The opposite was true for $\mathrm{B}$. The $\mathrm{P}$ and $\mathrm{Mg}$ content of flower were quite equal with leaf $\mathrm{P}$ and $\mathrm{Mg}$ at full bloom. All examined nutrients were significantly affected by cultivars both in flowers and leaves. Significant correlation, was found between flower $\mathrm{P}$ and leaf $\mathrm{P}$, flower $\mathrm{B}$ and leaf $\mathrm{B}$ ( $\mathrm{P}=0.01$ ) and flower $\mathrm{K}$ and leaf $\mathrm{K}$ at blooming time $(\mathrm{P}=0.05)$. Significant, but weaker correlation was also found between flower $\mathrm{K}$ and leaf $\mathrm{K}$ and between flower $\mathrm{Mg}$ and leaf $\mathrm{Mg}$ at 100 days after full bloom $(\mathrm{P}=0.05)$. Moreover, strong, but negative correlation was observed between flower $\mathrm{B}$ and leaf $\mathrm{B}$ at 100 days after full bloom $(\mathrm{P}=0.01)$. Within flowers, the strongest positive correlation was found between $\mathrm{Mg}$ and $\mathrm{B}$ content $(\mathrm{P}=0.01)$. Strong positive correlations were also recognised between flower $\mathrm{K}$ and flower $\mathrm{N}, \mathrm{Ca}$ and $\mathrm{Mg}$ and between $\mathrm{N}$ and $\mathrm{Ca}$ in the flowers $(\mathrm{P}=0.01)$. The strongest correlation was found between $\mathrm{K}$ and $\mathrm{P}$ in leaves at full bloom $(\mathrm{P}=0.01)$. Strong significant correlation was observed between $\mathrm{N}$ and $\mathrm{B}$ in the leaves collected at standard sampling time (100 DAFB) $(\mathrm{P}=0.01)$. Strong, but negative correlations were found between leaf $\mathrm{Mg}$ and leaf $\mathrm{P}, \mathrm{K}$ and between leaf $\mathrm{N}$ and leaf $\mathrm{P}$ at 100 days after full bloom $(\mathrm{P}=0.01)$.

Key words: floral analysis, fruit nutrition, apple, soil-flower-leaf nutrient interactions

\section{Introduction}

To achieve adequate plant nutrition it's essential for growers to diagnose the nutritional status of their crops in time. At present, it is mainly done by means of plant material (mostly leaf) analysis. This method is based on the fact that the leaf is the main site of plant metabolism. Out of this, the changes in nutrients supply are reflected in leaf composition, being more pronounced at certain development stages; and that the concentration of nutrients in the leaf at specific growth stages are related to the performance of the crop (Bould, 1966).

Leaf analysis integrates all the factors that might influence soil nutrient availability and plant uptake, and pinpoints the nutritional balance of the plant at the time of sampling (Pestana et al., 2004).

Although leaf analysis has spread all over the world and provides useful information about nutritional status it has weakness and some disadvantages. It is true for fruit nutrition especially. The main limitation of leaf analysis is that the sampling date recommended for fruit trees is late in the growing season, generally very close to harvest (Sanz et al., 1995; Sanz and Montañés, 1995; Belkhodja et al., 1998).
At this point it is no longer possible to correct nutritional disorders in time to avoid decreases in yield (Sanz and Montañés, 1995). It is therefore important to develop alternative methods to diagnose deficiency symptoms in fruit trees so that remedial action can be taken before yield is affected.

Firstly, Sanz et al. (1993) suggested a novel approach for the prognosis of iron deficiency in pear trees. They used the mineral composition of flowers to estimate the nutritional status of trees. These authors stated that floral analysis could be used to determine the nutritional status of fruit trees at an early stage, since the mineral composition of flowers at full bloom is often related to the nutrient content in leaves taken later in the season. Flower analysis has now been developed for a number of deciduous fruit trees: pear (Sanz et al., 1993, 1994), peach (Belkhodja et al., 1998; Igartua et al., 2000; Sanz et al., 1997; Holb, 2008), nectarine (Toselli et al., 2000), apple (Morales et al., 1998; Sanz et al., 1998) and almond (Bouranis et al., 2001).

Montañés Millán et al. (1997) pointed out that floral analysis could permit an early diagnosis to prognose an abnormal nutritive situation, before symptoms are perceivable.

Another limitation of leaf analysis is that the complexity of photosynthetic function in leaves determine that elements 
involved in these processes remain inactive or blocked, thus masking the diagnosis (Sanz et el., 1998).

Although, floral analysis can be used as an early method to diagnose nutritional status of fruit trees in several countries all over the world data on the mineral composition of apple flowers had not been published previously in Hungary.

In this work, I tested the possibility of using the mineral composition of flowers to diagnose nutritional status of six apple (Malus domestica Borkh.) cultivars earlier than standard sampling time. Furthermore, results of floral analysis compared to the results of traditional leaf analysis.

\section{Materials and methods}

Investigations were carried out in an apple orchard (Malus domestica Borkh.) of TEDEJ Rt., Hajdúnánás-Tedej, in Eastern Hungary in 2008. The orchard was set up on lowland chernozem soil. It was established in the autumn of 1999 , using grafted on MM106 rootstocks at a spacing of $3.8 \times 1.1 \mathrm{~m}$. The orchard has been treated according to the Integrated Fruit Production guidelines.

The orchard was irrigated. Soil samples were taken from three layers $(0-20 \mathrm{~cm} ; 20-40 \mathrm{~cm}$ and $40-60 \mathrm{~cm})$ of each plot, at the middle of the section by using manual soil sampling equipment. For the characterisation of the soil the most important soil parameters were determined. Sampling was performed at the beginning of the vegetation period on March, in 2008.

The soil samples were dried outdoors in an airy place in a $1-1.5 \mathrm{~cm}$ layer, then the soil was sieved through a sieve of 2 $\mathrm{mm}$ hole size, homogenized and stored in plastic boxes until the examination. For extracting the available phosphorus and potassium content of soils, ammonium-lactate extractant (so called AL soluble) was used. AL soluble phosphorus was quantified by colorimetrically with phospomolybdovanadate method, using a spectrophotometer (Metertech VIS SP-850 Plus; Metertech Inc., Taipei, Taiwan). The amount of potassium was quantified by flame atom emission spectrophotometry method using an Unicam SP90B Series 2 Atomic Absorption/Emission Spectrophotometer (PYE Unicam, England).

Mineralized nitrogen contents of soil samples were quantified according to Houba et al. 1986.

Soil $\mathrm{pH}, \mathrm{K}_{\mathrm{A}}, \mathrm{H} \%$ and $\mathrm{CaCO}_{3}$ content determinated according to Hungarian standards (MSZ 20135:1999).

For extracting the available $\mathrm{Mg}, \mathrm{Cu}, \mathrm{Zn}$ and $\mathrm{Mn}$ contents of soils $\mathrm{KCl}+$ EDTA extractant was used according to Hungarian soil laboratory guidelines (MSZ 20135:1999).

The amount of these elements in the soil was quantified by flame atomic absorption spectrophotometry, using a SpectrAA-10 Plus spectrophotometer (Varian Australia Pty Ltd. Mulgrave, Australia).

For extracting the plant available B hot water was used. The extracted $\mathrm{B}$ was measured by photometric method (Azomethin-H method) using a spectrophotometer
(Metertech VIS SP-850 Plus; Metertech Inc., Taipei, Taiwan).

For plant analysis the following apple cultivars were selected: 'Idared'; 'Summerred'; 'Jonagold'; 'Braeburn'; 'Golden Reinders'; 'Mutsu'.

Flower samples were collected at full bloom on 26 April 2008. Leaf samples were collected at the same time and later, on 1 August 2007, from 50 trees according to Nagy et al., 2006. Flowers were collected according to Sanz and Montañés, 1995.

Flower and leaf samples were dried outdoors in an airy place for a week. After drying samples in a well-ventilated drying oven for $6 \mathrm{hrs}$ at $40 \mathrm{C}$, the whole sampled material was finely grounded and homogenized. Samples were then stored in paper bags in a dark and dry place until use.

Nitrogen content of plant samples was determined from homogenized samples directly using the dry combustion method according to Nagy 2000, using an Elementar Vario EL analyser (Elementar Analysensysteme GmbH, Hanau, Germany).

$\mathrm{Ca}, \mathrm{Mg}, \mathrm{Cu}, \mathrm{Zn}$ and $\mathrm{Mn}$. Plant phosphorus and potassium contents determine as follows: homogenized leaf samples ( $0.5 \mathrm{~g}$ each sample) were digested with cc. $5 \mathrm{ml} \mathrm{H}_{2} \mathrm{SO}_{4}$ and 5 $\mathrm{ml} \mathrm{H}_{2} \mathrm{O}_{2}$ in a heating block digestor, at $220 \mathrm{C}$ until full digestion. For determining leaf calcium and magnesium nitric acid digestion was used.

For leaf boron analysis $1 \mathrm{~g}$ plant sample was ashed in a muffle furnace at $450^{\circ} \mathrm{C}$. Ash was dissolved in $5 \mathrm{ml}$ of a $1 \mathrm{M}$ $\mathrm{HCl}$ at room temperature, mixed, and measured as described above at soil samples.

\section{Statistical analysis}

For investigations 20 trees were selected by a completely randomised design with uniform characteristics. Pearson correlations were applied between the nutrient concentration of apple flowers and leaves collected different sampling times.

\section{Results and discussion}

\section{Soil analysis}

Obtained results of soil analysis are represented in Table 1.

Table 1. Results of soil analysis

\begin{tabular}{|l|c|c|c|c|}
\hline \multirow{2}{*}{ Parameters } & \multicolumn{4}{|c|}{ Depth $(\mathbf{c m})$} \\
\cline { 2 - 5 } & $\mathbf{0 - 2 0}$ & $\mathbf{2 0 - 4 0}$ & $\mathbf{4 0 - 6 0}$ & $\mathbf{0 - 6 0}$ \\
\hline $\mathrm{Humusz} \%$ & 2.75 & 2.23 & 2.05 & 2.34 \\
$\mathrm{~K}_{\mathrm{A}}$ & & & & 43 \\
$\mathrm{pH}(\mathrm{KCl})$ & 6.46 & 6.24 & 6.31 & 6.34 \\
$\mathrm{CaCO}_{3}(\%)$ & $<0.1$ & $<0.1$ & 0.5 & 0.5 \\
$\mathrm{P}_{2} \mathrm{O}_{5}(\mathrm{mg} / \mathrm{kg})$ & 164.11 & 89.12 & 42.7 & 98.64 \\
$\mathrm{~K}_{2} \mathrm{O}(\mathrm{mg} / \mathrm{kg})$ & 250.44 & 160.69 & 98.65 & 169.93 \\
$\mathrm{NO}_{3}^{-}-\mathrm{N}(\mathrm{mg} / \mathrm{kg})$ & 13.05 & 8.29 & 5.25 & 8.86 \\
$\mathrm{NH}_{4}^{+}-\mathrm{N}(\mathrm{mg} / \mathrm{kg})$ & 1.05 & 0.76 & 0.19 & 0.67 \\
$\mathrm{Mg}(\mathrm{mg} / \mathrm{kg})$ & 188 & 164 & 155 & 169 \\
$\mathrm{~B}(\mathrm{mg} / \mathrm{kg})$ & 0.76 & 0.55 & 0.44 & 0.58 \\
\hline
\end{tabular}


Besides conventional soil testing procedures, $0.01 \mathrm{M}$ $\mathrm{CaCl}_{2}$ was used to give further information about the easily soluble and available mineral $\mathrm{N}$ contents of soil. The $\mathrm{pH}$ of soil was near the neutral value, slightly acidic. The physical category of soil was clay loam. The soil P and K was weak, while the soil $\mathrm{N}$ was adequate for growing.

From the easily soluble $\mathrm{N}$ forms the nitrate was dominant. Measured values correspond to the type of examined soil and decreased by depth. The micronutrient contents of soil were medium.

\section{Plant analysis}

The N, P, K, Ca Mg and B content of flower and leaf of apple cultivars at full bloom (FB) and 100 days after full bloom (100 DAFB) is shown in Table 2-3.
The highest amount was $\mathrm{N}$ while the smaller amount was $\mathrm{B}$ in flowers. The N, K and Ca content were higher in leaves than in flowers at full bloom. The opposite was true for B. The $\mathrm{P}$ and $\mathrm{Mg}$ content of flower were quite equal with leaf $\mathrm{P}$ and $\mathrm{Mg}$ at full bloom. These results confirm earlier observations obtained by sweet cherry (Betrán et al., 1998) and orange (Pestana et al., 2004).

As amounts of nutrients are changing during the growing season, their ratios between flowers and leaves are changing also. It means that sampling dates affected the values and the fluctuation of examined nutrients.

For all sampling dates, the range of $\mathrm{N}, \mathrm{P}$ and $\mathrm{K}$ contents were wider in leaves than that found in flowers. The narrowest range of $\mathrm{Ca}$ and $\mathrm{Mg}$ were found in leaves at 100 days after full bloom. Relatively wide boron fluctuation was found both in flower and leaf samples at full bloom.

Table 2. N, P and K content (\% d.m.) of flowers and leaves at full bloom and 100 days after full bloom

\begin{tabular}{|c|c|c|c|c|c|c|c|c|c|}
\hline \multirow{2}{*}{ Cultivars } & \multicolumn{3}{|c|}{ Flowers (FB) } & \multicolumn{3}{|c|}{ Leaves (FB) } & \multicolumn{3}{|c|}{ Leaves (100 DAFB) } \\
\hline & $\mathrm{N}(\%)$ & $\mathbf{P}(\%)$ & $\mathbf{K}(\%)$ & $\mathbf{N}(\%)$ & $\mathbf{P}(\%)$ & $\mathbf{K}(\%)$ & $\mathbf{N}(\%)$ & $\mathbf{P}(\%)$ & $\mathbf{K}(\%)$ \\
\hline Idared & 2.74 & 0.34 & 1.79 & 3.26 & 0.33 & 1.02 & 1.73 & 0.28 & 1.40 \\
\hline Summerred & 2.68 & 0.35 & 1.85 & 3.74 & 0.37 & 1.24 & 1.70 & 0.38 & 1.84 \\
\hline Jonagold & 2.38 & 0.34 & 1.75 & 3.28 & 0.34 & 1.07 & 1.89 & 0.14 & 1.05 \\
\hline Braeburn & 2.82 & 0.38 & 1.92 & 3.29 & 0.44 & 1.47 & 1.91 & 0.34 & 1.75 \\
\hline Golden Reinders & 2.71 & 0.35 & 1.81 & 3.35 & 0.39 & 1.24 & 1.93 & 0.25 & 1.19 \\
\hline Mutsu & 2.47 & 0.35 & 1.64 & 3.40 & 0.37 & 1.15 & 2.25 & 0.18 & 1.82 \\
\hline Average & 2.63 & 0.35 & 1.79 & 3.39 & 0.37 & 1.20 & 1.90 & 0.26 & 1.51 \\
\hline $\mathrm{LSD}_{5 \%}$ & 0.13 & 0.01 & 0.08 & 0.14 & 0.03 & 0.13 & 0.16 & 0.08 & 0.28 \\
\hline
\end{tabular}

Table 3. Ca, $\mathrm{Mg}(\% \mathrm{~d} . \mathrm{m}$.) and $\mathrm{B}(\mathrm{mg} / \mathrm{kg})$ content of flowers and leaves at full bloom and 100 days after full bloom

\begin{tabular}{|c|c|c|c|c|c|c|c|c|c|}
\hline \multirow[b]{2}{*}{ Cultivars } & \multicolumn{3}{|c|}{ Flowers (FB) } & \multicolumn{3}{|c|}{ Leaves (FB) } & \multicolumn{3}{|c|}{ Leaves (100 DAFB) } \\
\hline & $\begin{array}{c}\mathrm{C} \\
(\%) \\
\end{array}$ & $\begin{array}{l}\mathrm{Mg} \\
(\%) \\
\end{array}$ & $\begin{array}{c}\text { B } \\
(\mathbf{m g} / \mathbf{k g}) \\
\end{array}$ & $\begin{array}{c}\text { C } \\
(\%)\end{array}$ & $\begin{array}{l}\mathrm{Mg} \\
(\%)\end{array}$ & $\begin{array}{c}\text { B } \\
(\mathrm{mg} / \mathrm{kg}) \\
\end{array}$ & $\begin{array}{c}\mathrm{C} \\
(\%) \\
\end{array}$ & $\begin{array}{l}\mathrm{Mg} \\
(\%)\end{array}$ & $\begin{array}{c}\text { B } \\
(\mathrm{mg} / \mathrm{kg})\end{array}$ \\
\hline Idared & 0.47 & 0.25 & 55.83 & 0.78 & 0.26 & 32.25 & 1.24 & 0.22 & 41.01 \\
\hline Summerred & 0.43 & 0.25 & 57.05 & 0.90 & 0.29 & 38.98 & 1.34 & 0.23 & 35.49 \\
\hline Jonagold & 0.35 & 0.25 & 51.74 & 0,46 & 0.23 & 36.14 & 1.17 & 0.30 & 39.43 \\
\hline Braeburn & 0.50 & 0.24 & 46.07 & 0.97 & 0.24 & 34.73 & 1.00 & 0.20 & 42.19 \\
\hline Golden Reinders & 0.35 & 0.24 & 54.57 & 0.46 & 0.26 & 42.88 & 1.39 & 0.30 & 36.28 \\
\hline Mutsu & 0.34 & 0.19 & 44.29 & 0.65 & 0.24 & 28.64 & 1.38 & 0.27 & 44.16 \\
\hline Average & 0.41 & 0.24 & 51.59 & 0.70 & 0.25 & 35.60 & 1.25 & 0.25 & 39.76 \\
\hline $\mathrm{LSD}_{5 \%}$ & 0.06 & 0.02 & 4.24 & 0.18 & 0.02 & 4.00 & 0.12 & 0.03 & 2.71 \\
\hline
\end{tabular}

\section{Comparison between plant parts at full bloom and 100 days} after full bloom

In flowers the following ratio was found between nutrients: $\mathrm{N}: \mathrm{P}: \mathrm{K}: \mathrm{Ca}: \mathrm{Mg}: \mathrm{B} \sim 10: 1.35: 7: 1.7: 1: 0,02$. The ratios of examined nutrients similar those obtained by leaf. Moreover, flowers contain significant amount of boron compared to the leaves (Wojcik, 2006; Peryea 1994). Obtained results are in good correlations with earlier findings (Morales et al., 1998; Sanz et al., 1998).

From results it was evident that flower as organ contain significant and comparable amount of nutrients like as leaf.
Moreover, all examined nutrients were significantly affected by cultivars both in flowers and leaves.

Nutrient correlations between different plant parts and sampling times

The correlations between different plant parts and sampling times within nutrients were studied also (Table 4.). No significant correlations were found between flower and leaf $\mathrm{N}$ and $\mathrm{Ca}$ at any sampling date. Moreover, weak and negative correlation was found between leaf $\mathrm{N}$ at full bloom and leaf $\mathrm{N}$ at 100 days after full bloom. 
Table 4. Correlation coefficients ( $\mathrm{r}$ ) between flowers and leaves at the same and later sampling time, and between leaves and leaves at different sampling time

\begin{tabular}{|c|c|c|c|c|c|}
\hline $\mathbf{N}$ & $\mathbf{P}$ & $\mathbf{K}$ & $\mathbf{C a}$ & $\mathbf{M g}$ & $\mathbf{B}$ \\
\hline $\begin{array}{c}\text { Flowers and leaves at FB } \\
0.1328\end{array}$ & $0.7918^{* * *}$ & $0.5352^{*}$ & 0.2739 & 0.4527 & $0.6972 * *$ \\
\hline $\begin{array}{c}\text { Flowers and leaves at 100 DAFB } \\
-0.0209\end{array}$ & 0.2814 & $0.4921^{*}$ & -0.2624 & $0.5116^{*}$ & $-0.7416^{* *}$ \\
\hline $\begin{array}{c}\text { Leaves at FB and leaves at } \\
\text { 100 DAFB } \\
-0.1849\end{array}$ & 0.3887 & 0.0311 & -0.1971 & $0.7467 * *$ & $-0.7799^{* * *}$ \\
\hline
\end{tabular}

Significant at $\mathrm{P}=0.05\left(^{(*)}\right.$ or $\mathrm{P}=0.01{ }^{(* *)}$
Similar result was observed regarding Ca. Significant correlation, however, was found between flower $\mathrm{P}$ and leaf $\mathrm{P}$, flower $\mathrm{B}$ and leaf $\mathrm{B}(\mathrm{P}=0.01)$ and flower $\mathrm{K}$ and leaf $\mathrm{K}$ at was also found between flower $\mathrm{K}$ and leaf $\mathrm{K}$ and between flower $\mathrm{Mg}$ and leaf $\mathrm{Mg}$ at 100 days after full bloom ( $\mathrm{P}=0.05$ ). Strong, but negative correlation was observed between flower B and leaf $\mathrm{B}$ at 100 days after full bloom $(\mathrm{P}=0.01)$. Strong positive correlation was found between leaf $\mathrm{Mg}$ at full bloom and leaf $\mathrm{Mg}$ at 100 days after full bloom ( $\mathrm{P}=0.01)$. Moreover, similarly to those obtained between flower B and leaf B collected 100 days after blooming, strong $(\mathrm{P}=0.01)$ negative correlation was

The correlations between nutrients in flowers and leaves of apple trees were also calculated (Table 5.). Within blooming time ( $\mathrm{P}=0.05)$. Significant, but weaker correlation found between leaf B (FB) and leaf B (100 DAFB). flowers, the strongest positive correlation was found between $\mathrm{Mg}$ and $\mathrm{B}$ content $(\mathrm{P}=0.01)$. Strong positive correlations were also recognised between flower $\mathrm{K}$ and flower $\mathrm{N}, \mathrm{Ca}$ and $\mathrm{Mg}$ and between $\mathrm{N}$ and $\mathrm{Ca}$ in the flowers $(\mathrm{P}=0.01)$. Weaker, but significant correlation was also observed between flower $\mathrm{K}$ and flower $\mathrm{P}(\mathrm{P}=0.05)$. Similar, but weaker correlations were found between $\mathrm{N}$ and $\mathrm{P}$ in the flowers $(\mathrm{P}=0.05)$. This could suggest that strong relationship has between nutrients within flowers.

The strongest correlation was found between $\mathrm{K}$ and $\mathrm{P}$ in leaves at full bloom $(\mathrm{P}=0.01)$. Weaker, but significant correlation was detected between leaf $\mathrm{K}$ and leaf $\mathrm{Ca}$, leaf $\mathrm{Mg}$ and leaf $\mathrm{B}$ at this sampling time $(\mathrm{P}=0.05)$. Weak correlation was found between leaf $\mathrm{Ca}$ and leaf $\mathrm{P}$ at the same time (Table 5.). Strong significant correlation was observed between $\mathrm{N}$ and $\mathrm{B}$ in the leaves collected at standard sampling time $(100$ $\mathrm{DAFB})(\mathrm{P}=0.01)$.

Strong, but negative correlations were found between leaf $\mathrm{Mg}$ and leaf $\mathrm{P}, \mathrm{K}$ and between leaf $\mathrm{N}$ and leaf $\mathrm{P}$ at 100 days after full bloom $(\mathrm{P}=0.01)$. Moreover, positive significant but weaker correlation was detected between leaf $\mathrm{Mg}$ and leaf $\mathrm{Ca}$ at the standard sampling date $(\mathrm{P}=0.05)$. Notable, that B was negatively correlated with $\mathrm{P}, \mathrm{Ca}$ and $\mathrm{Mg}$ in the leaves at 100 DAFB.
Table 5. Correlations coefficients ( $\mathrm{r}$ ) between $\mathrm{N}, \mathrm{P}$ and $\mathrm{K}$ contents in flowers and leaves of apple trees

\begin{tabular}{|c|c|c|c|c|c|c|}
\hline & $\mathbf{N}$ & $\mathbf{P}$ & $\mathbf{K}$ & Ca & Mg & B \\
\hline \multicolumn{7}{|c|}{ Within flowers } \\
\hline $\mathbf{N}$ & 1 & & & & & \\
\hline $\mathbf{P}$ & 0.4886 & 1 & & & & \\
\hline $\mathbf{K}$ & $0.7764 * *$ & $0.5029^{*}$ & 1 & & & \\
\hline $\mathrm{Ca}$ & $0.7824 * *$ & 0.4011 & $0.7655^{* *}$ & 1 & & \\
\hline Mg & 0.3981 & -0.2492 & $0.6890^{* *}$ & 0.4607 & 1 & \\
\hline B & 0.2374 & $-0.6176^{*}$ & 0.3086 & 0.1193 & $0.8041^{* *}$ & 1 \\
\hline \multicolumn{7}{|c|}{ Within leaves at full bloom } \\
\hline $\mathbf{N}$ & 1 & & & & & \\
\hline $\mathbf{P}$ & 0.0159 & 1 & & & & \\
\hline K & 0.1672 & $0.9823^{* *}$ & 1 & & & \\
\hline $\mathrm{Ca}$ & 0.3441 & 0.4325 & $0.5060^{*}$ & 1 & & \\
\hline Mg & $0.7262 * *$ & -0.0306 & 0.0475 & 0.3515 & 1 & \\
\hline B & 0.2906 & 0.2318 & 0.2709 & -0.2465 & $0.4778^{*}$ & 1 \\
\hline \multicolumn{7}{|c|}{ Within leaves at 100 days after full bloom } \\
\hline $\mathbf{N}$ & 1 & & & & & \\
\hline $\mathbf{P}$ & $-0.5952 * *$ & 1 & & & & \\
\hline K & 0.1756 & $0.5712^{* *}$ & 1 & & & \\
\hline $\mathrm{Ca}$ & 0.2254 & -0.1595 & 0.0170 & 1 & & \\
\hline Mg & 0.3938 & $-0.7796^{* *}$ & $-0.6572 * *$ & $0.4957^{*}$ & 1 & \\
\hline B & $0.6331 * *$ & -0.3762 & 0.2889 & -0.3367 & -0.2303 & 1 \\
\hline
\end{tabular}

Significant at $\mathrm{P}=0.05(*)$ or $\mathrm{P}=0.01\left(^{* *}\right)$

\section{Conclusions}

Obtained findings permit us to conclude that:

1) Mineral composition of flowers similar to those obtained at leaves.

2) Nutrients in flowers similarly affected by cultivars than in leaves.

3) Strong correlations were observed between elements in flowers.

4) Nutrient values correlated with themselves between different plant parts

5) Some strong correlations were found between nutrients according to plant parts and sampling times.

Moreover, it seems from obtained result that to generalize on the use of floral analysis as an early diagnostic method to establish nutritional status of fruit trees further investigations will be necessary to apply this method with greatly soundness. 


\section{References}

Belkhodja, R., Morales, F., Sanz, M., Abad'ýa, A. \& Abad'ýa, J. (1998): Iron deficiency in peach trees: effects on leaf chlorophyll and nutrient concentrations in flowers and leaves. Plant and Soil. 203: 257-268.

Bould, C. (1966): (In: Childers, N.F. (Ed.), Leaf Analysis of Deciduous Fruits. Fruit Nutrition.) Horticultural Publications, New Jersey.

Bouranis, D. L., Chorianopoulou, S. N., Zakynthinos, G., Sarlis, G. \& Drossopoulos, J. B. (2001): Flower analysis for prognosis of nutritional dynamics of almond tree. J. Plant Nutr. 24: 705-716.

Igartua, E., Grasa R., Sanz M., Abadía A. \& Abadía J. (2000): Prognosis of iron chlorosis from the mineral composition of flowers in peach. J. Hort. Sci. Biotec. 75: 111-118.

Holb, I.J. (2008): Diseases and pests in the flowers of fruit trees. p. 393-438. (In: Nyéki, J., Soltész, M. Szabó, Z. Morphology, biology, and fertility of flowers in temperate zone fruits.) Akadémia Kiadó, Budapest.

Houba, V.J.G., Novozamsky, I., Huijbregts, A.W.M. \& Lee, van der, J.J. (1986): Comparison of soil extractions by $0.01 \mathrm{CaCl}_{2}$ by EUF and by some conventional extraction procedures. Plant and Soil. 96: 433-437.

MI-08 0468-81: Plant analyses. Orchards. Sampling, preparation of samples, storing of samples. Hungarian Standards Institution. Ministry of Agriculture. Budapest (in Hungarian)

Montañés Millán, L., J. Val, J. Bertrán, E. Monge, M.A. Moreno \& L. Montañés (1997): Floral analysis: Fresh and dry weight of flowers from different fruit tree species. Acta Horticulturae. 448: 233-239.

Morales, F., Grasa R., Abadía A. \& Abadía J. (1998): Iron chlorosis paradox in fruit trees. J. Plant Nutr. 21: 815-825.

MSZ-08 0202-77: Sampling soils for management purposes in agriculture. Hungarian Standards Institution. Ministry of Agriculture. Budapest (in Hungarian)

MSZ 20135:1999: Determination of the soluble nutrient element content of the soil. Hungarian Standards Institution. Budapest (in Hungarian)
Nagy, P.T. (2000): Application of an element analyser for soil and plant analyses (dry combustion method). Agrokémia és Talajtan. 49: 521-534.

Nagy, P. T. and I. J. Holb (2006): Study on the macronutrient content of apple leaves in an organic apple orchard. Journal of Central European Agriculture. 7: (2) 329-336.

Peryea F.J. (1994): Boron nutrition in deciduous tree fruit, p. 95-99. (In: A.B. Peterson and R.G. Stevens (eds.). Tree fruit nutrition.) Good Fruit Grower, Yakima, Wash.

Pestana M., A. de Varennes, M. J. Goss,, J. Abadía \& E. A. Faria (2004): Floral analysis as a tool to diagnose iron chlorosis in orange trees. Plant and Soil. 259: 287-295.

Sanz, M. \& Montañés, L. (1995): Flower analysis as a new approach to diagnosing the utritional status of the peach tree. Journal of Plant Nutrition. 18: 1667-1675.

Sanz, M., M. Carrera \& L. Montañés (1993): El estado nutricional del perar. Possibildad del diagnóstico floral. Hortofruticultura 10. 60-62. (In: Pestana M.; A. de Varennes; M. J. Goss,; J. Abadía and E. A. Faria: Floral analysis as a tool to diagnose iron chlorosis in orange trees.) Plant and Soil. 259: 287-295, (2004.)

Sanz, M., J. Val, E. Monge \& L. Montañés (1995): Is it possible to diagnose the nutritional status of peach trees by chemical analysis of their flowers? Acta Horticulturae. 383: 159-163.

Sanz, M., Montañés L. \& Carrera M. (1994): The possibility of using flower analysis to diagnose the nutritional status of pear trees. Acta Horticulturae. 367: 290-295.

Sanz, M., Pérez J., Pascual J. \& Machín J. (1998): Prognosis of iron chlorosis in apple trees by floral analysis. J. Plant Nutr. 21: $1697-1703$.

Sanz, M., Belkhodja R., Toselli M., Montañés L., Abadía A. Tagliavini M., Marangoni B. \& Abadía J. (1997): Floral analysis as a possible tool for prognosis of iron deficiency in peach. Acta Horticulturae. 448: 241-245.

Toselli, M., Marangoni B. \& Tagliavini M. (2000): Iron content in vegetative and reproductive organs of nectarine trees in calcareous soils during the development of chlorosis. Eur. J. Agron. 13: 279-286. 